\title{
Determination of the Actual Amount of Insolation Absorbed by a Photovoltaic Panel (125w)
}

\author{
Rex Kemkom Chima Amadi*, Anthony Kpegele Leol \\ Department of Mechanical Engineering, Rivers State University, Port Harcourt, Nigeria \\ Email address: \\ amadikemkom@gmail.com (R. K. C. Amadi), kemkom.amadi1@ust.edu.ng (R. K. C. Amadi), amadikemkom@gmail.com (A. K. Leol), \\ leol.anthony@ust.edu.ng (A. K. Leol) \\ ${ }^{*}$ Corresponding author
}

\section{To cite this article:}

Rex Kemkom Chima Amadi, Anthony Kpegele Leol. Determination of the Actual Amount of Insolation Absorbed by a Photovoltaic Panel (125w). Science Journal of Energy Engineering. Vol. 6, No. 1, 2018, pp. 27-30. doi: 10.11648/j.sjee.20180601.14

Received: March 2, 2018; Accepted: March 20, 2018; Published: April 14, 2018

\begin{abstract}
The determination of the ability of the Photovoltaic cell in absorbing radiation was performed, taking into cognizance the fact that photovoltaic panels have the ability to harness solar energy incident on it in the form of radiation. It utilized the hourly production of open circuit voltage for a $125 \mathrm{~W}$ module Photovoltaic panel made of silicon material. The solar panel was exposed to the open atmosphere from sunrise to sunset, precisely from 5.00am to 7.00am, with no obstruction from heights, high rise buildings and tall trees including towers. The photovoltaic panel was brought to ambient temperature and results were taken in clear sky weather condition in the neighborhood of \pm 10 minutes to the hour mark. The voltage output was recorded with the aid of a digital multimeter and a Power model was used to determine the actual amount of radiation available and a plot of voltage V hours and Watt V hour when done, showed the same pattern as that of Adnot, Haurwitz and Alboteani et al. results. The hourly variation of voltage graph when assessed, showed an ascendancy as the hour increased to a maximum of 20.65 Volts at mid day and then a decrease to 0 volts at twilight $(7.00 \mathrm{pm})$ on the $11^{\text {th }}$ day of November, 2017 . The same ascendancy and decrease patterns were also displayed by the hourly variation of absorbed power. Thus, photovoltaic panel output varies with the sun hours like solar radiation varies with the sun hours, when results are obtained are obtained under stated conditions. Hence, results stands validated.
\end{abstract}

Keywords: Photovoltaic Plate, Solar Radiation, Sun Hour, Clear Sky Weather, Voltage Output and Power

\section{Introduction}

The energy radiated from the solar system releases Extraterrestrial radiation that reaches and impinges on Photovoltaic cells as terrestrial radiation. The most important characteristic of the Photovoltaic panel is its conversion efficiency, which expresses the amount of solar radiation available in the incident radiation [1]. Empirical calculation of Extraterrestrial radiation have been done in the works of [2-6] etc.

Alboteanu et al, placed global radiation as

$$
\mathrm{G}_{\mathrm{g}}=\left(\frac{24}{\pi}\right) \times s\left(0.33 \cos \left(\frac{2 \pi n}{365}\right) \cos \vartheta \sin \alpha_{\mathrm{s}}+\omega_{\mathrm{s}} \sin \emptyset \sin \delta\right.
$$

Where $\mathrm{S}=$ Solar constant

$\mathrm{G}_{\mathrm{g}=}$ Global radiation

$\mathrm{n}=$ no. days of the year $\emptyset=$ latitude

$\omega_{\mathrm{s}}=$ Solar angle

$\delta=$ Declination angle

His work also showed the calculation of Terrestrial irradiation. The extract identified empirical models which calculated the amount of solar radiation present with respect to the time of the day and had the highest insolation at noon day for clear sky conditions. These models were

The Adnot model: $G_{\mathrm{g}}=953.9\left(\sin \alpha_{\mathrm{s}}\right)^{1.5} \mathrm{w} / \mathrm{s}$

Haurwitz model: $\left.\mathrm{Gg}=1.098) \mathrm{e}^{(0.057 / \mathrm{sin}} \alpha^{\mathrm{s})} \sin \alpha_{\mathrm{s}}\right) \mathrm{w} / \mathrm{m}^{2}$

Kasten model $=\mathrm{Gg}=910\left(\sin \alpha_{\mathrm{s}}\right)-30 \mathrm{w} / \mathrm{m}^{2}$

Empirical EIM by Paulescu and Schlet

Where $\alpha_{s}=$ angle between sun and horizontal hsin $\alpha_{\mathrm{s}}$

The business of this work is to calculate the actual amount of radiation absorbed by a $125 \mathrm{~W}$ module photovoltaic panel. This actual amount of absorbed radiation is calculated using a power model and the result tabulated in a table of open 
circuit voltages. This is in line with the work of [7], as it clearly stated that most meteorological stations did not have solar radiation data for hourly estimation, which is a necessary parameter for performance evaluation of solar energy systems if accurately done. It is of the essence to note that precise measurement of hourly and daily solar radiation is best done by automated materials[8].

The work further experimentally determined the hourly instantaneous open circuit voltage from dawn till twilight and used it to show the behavioral pattern of available radiation.

\section{Materials and Methods}

\subsection{Experimental Set up}

The following materials were utilized:
a) $125 \mathrm{~W}$ Photovoltaic panel
b) Clear sky weather condition
c) Multimeter

d) Cooling water at $25^{\circ} \mathrm{C}$

Procedure

a) Obtain a horizontal platform in an open space, without any aerial obstruction.

b) Record hourly readings of open circuit voltage $\left(\mathrm{V}_{\text {ocv }}\right)$ from 5:00am to $7.00 \mathrm{pm}$ on $18^{\text {th }}$ November, 2017.

c) Ensure that photovoltaic panel is at least at ambient temperature before recording $\mathrm{V}_{\mathrm{ocv}}$.

d) Plotgraph with $V_{\text {ocv }}$ V Hours

e) Plot graphs of actual power $\mathrm{V}$ hour andabsorbed power V hour.

\subsection{Power Model}

The power model is defined as: Power $(\mathrm{P})$ $\mathrm{p}=0.92 \mathrm{R}_{\mathrm{f}} \mathrm{P}_{\mathrm{i}} \delta$

Where $\mathrm{R}_{\mathrm{f}}=$ reflectivity of aluminum $\mathrm{P}_{\mathrm{i}}=$ standard inputs (power) $\delta=$ band absorbance of visible light

Table 1. Table of Voltages.

\begin{tabular}{|c|c|c|c|c|}
\hline S/No & Nominal Power provided (W) & Actual Power input $\left(0.92 R_{f} P_{i}\right)(W)$ & Power Absorbed $\left(K^{*} \mathrm{Pi}\right)(\mathrm{W})$ & $V_{\text {ocv-125 }}$ \\
\hline 01 & $60 \mathrm{w}$ & 55.2 & 25.39 & 13.3 \\
\hline 02 & 70 & 64.4 & 29.62 & \\
\hline 03 & 80 & 73.6 & 33.86 & \\
\hline 04 & 90 & 82.8 & 38.09 & \\
\hline 05 & 100 & 92 & 42.82 & \\
\hline 06 & 110 & 101.2 & 46.55 & \\
\hline 07 & 120 & 110.4 & 50.78 & 17.1 \\
\hline 08 & 130 & 119.6 & 55.02 & 17.4 \\
\hline 09 & 140 & 128.8 & 59.24 & 17.7 \\
\hline 10 & 150 & 138 & 63.48 & 18.0 \\
\hline 11 & 160 & 147.2 & 67.7 & 18.3 \\
\hline 12 & 170 & 156.4 & 71.9 & 18.6 \\
\hline 13 & 180 & 165.6 & 76.18 & 18.9 \\
\hline 14 & 190 & 174.8 & 80.41 & 19.2 \\
\hline 15 & 200 & 184 & 84.64 & 19.45 \\
\hline 16 & 210 & 190.8 & 88.87 & 19.7 \\
\hline 17 & 220 & 202.4 & 9.0 & 20.0 \\
\hline 18 & 230 & 211.6 & 97.34 & 20.2 \\
\hline 19 & 240 & 220.8 & 101.57 & 20.3 \\
\hline 20 & 250 & 230 & 105.8 & 20.4 \\
\hline 21 & 260 & 239.2 & 110.03 & 20.48 \\
\hline 22 & 270 & 248.4 & 114.26 & 20.52 \\
\hline
\end{tabular}

The above table was prepared for PVC module $125 \mathrm{~W}, \mathrm{~V}_{\max }=21.3 \mathrm{v}$ which gave actual $\mathrm{V}_{\max }=20.6 \mathrm{v}$. for Port Harcourt environment. [9]

\section{Results}

Table 2. Hour Table.

\begin{tabular}{|c|c|c|c|c|c|}
\hline & Time & Hour & $V_{\text {ocv }}(\mathbf{v})$ & Absorbed Power(w) & Actual $\mathbf{P}_{\mathrm{i}}(\mathbf{w})$ \\
\hline 1 & $5 \mathrm{am}$ & 5 & 0 & 0 & 0 \\
\hline 2 & $6 \mathrm{am}$ & 6 & 3.38 & 6.45 & 14.08 \\
\hline 3 & 7am & 7 & 17.44 & 55.02 & 119.6 \\
\hline 4 & $8 \mathrm{am}$ & 8 & 19.0 & 76.18 & 165.6 \\
\hline 5 & 9am & 9 & 20.0 & 93.1 & 202.4 \\
\hline 6 & $10 \mathrm{am}$ & 10 & 20.4 & 105.8 & 230 \\
\hline 7 & $11 \mathrm{am}$ & 11 & 20.5 & 114 & 248 \\
\hline 8 & $12 \mathrm{pm}$ & 12 & 20.65 & 135 & 294 \\
\hline 9 & $1 \mathrm{pm}$ & 13 & 20.5 & 114 & 248 \\
\hline 10 & $2 \mathrm{pm}$ & 14 & 20.3 & 101.57 & 220.8 \\
\hline 11 & $3 \mathrm{pm}$ & 15 & 20.0 & 93.1 & 202.4 \\
\hline
\end{tabular}




\begin{tabular}{llllll}
\hline & Time & Hour & $\mathbf{V}_{\text {ocv }}(\mathbf{v})$ & Absorbed Power(w) & Actual $\mathbf{P}_{\mathbf{i}}(\mathbf{w})$ \\
\hline 12 & $4 \mathrm{pm}$ & 16 & 19.0 & 76.18 & 165.9 \\
13 & $5 \mathrm{pm}$ & 17 & 17.45 & 55.02 & 119.6 \\
14 & $6 \mathrm{pm}$ & 18 & 3.4 & 6.45 & 14.08 \\
15 & $7 \mathrm{pm}$ & 19 & 0 & 0 & 0 \\
\hline
\end{tabular}

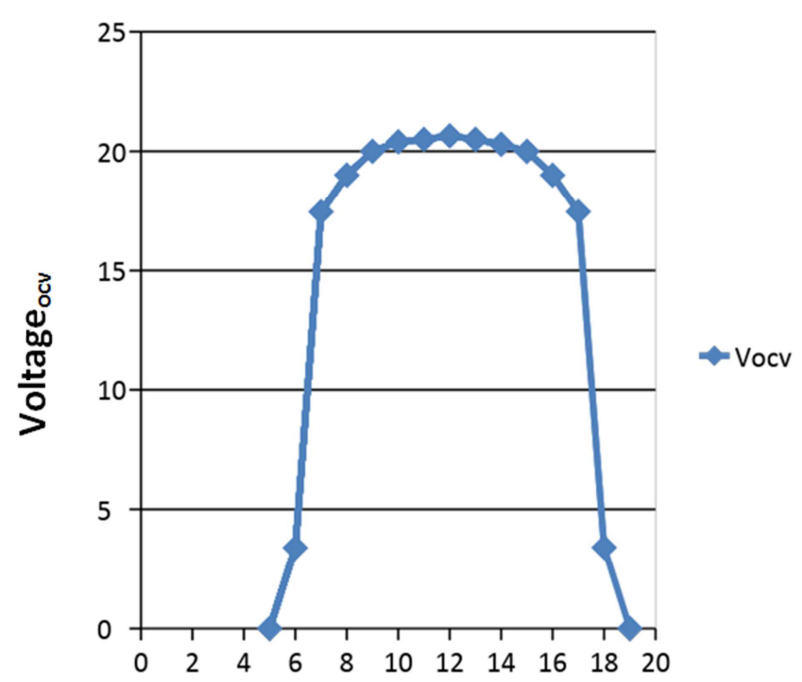

Hours

Figure 1. Hourly Variation of Voltage.

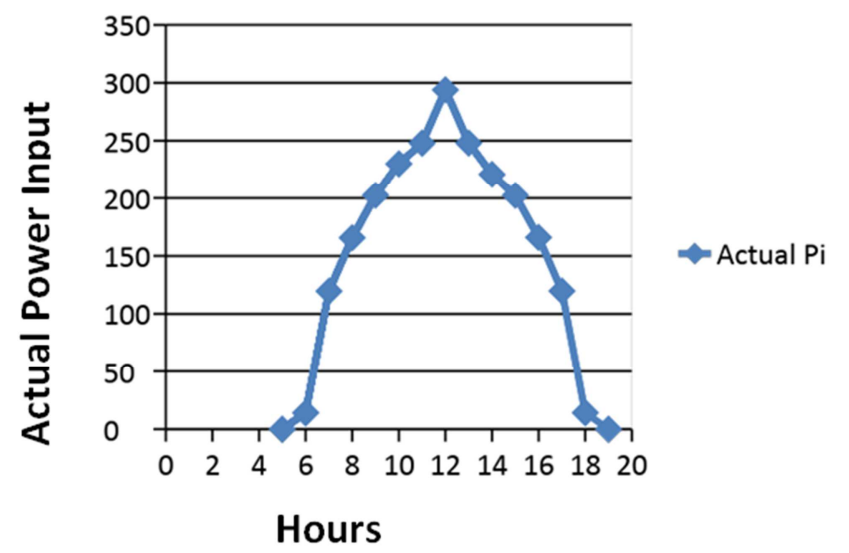

Figure 2. Hourly Variation of Actual Power Input.

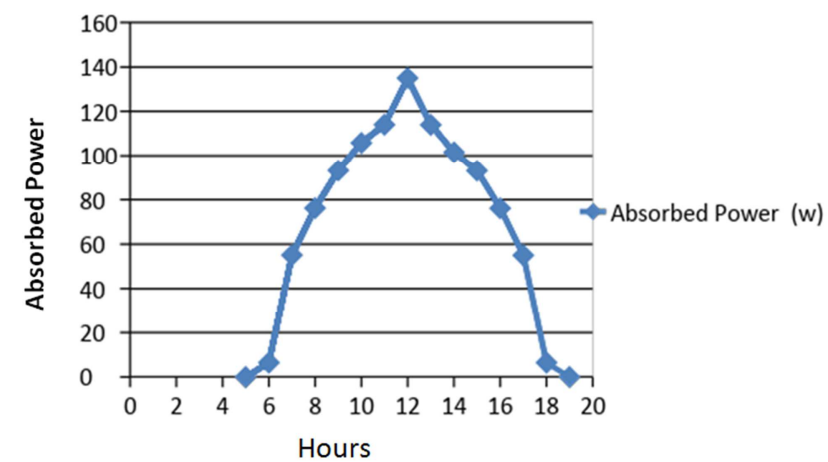

Figure 3. Hourly Variation with Absorbed Power by Photovoltaic Panel $(125 w)$.

\subsection{Calculation (Interpolation)}

For $\mathrm{V}_{\mathrm{ocv}} @ 3.38$,
Absorbed $\mathrm{P}_{\mathrm{i}}(\mathrm{x})$ is Actual $\mathrm{P}_{\mathrm{i}}(\mathrm{x})$ is

$$
\begin{gathered}
\frac{3.38-0}{13.3-0}=\frac{x-0}{25.39-0} \\
x=6.45 w \\
\frac{3.38-0}{13.3-0}=\frac{x-0}{55.2-0} \\
x=14.08 w
\end{gathered}
$$

\subsection{Discussion}

The table of voltages as introduced is used to denote and recognize the actual power absorbed by the Photovoltaic panel and the minimum amount of radiation capable of generating the corresponding open circuit voltage.

Figures 1 and 2 were used to present the hourly increase in the voltage and corresponding power respectively. In both figures, there is an increase from a value of zero at 5:00, to maximum of $20.6 \mathrm{~V}$ at $12.00 \mathrm{pm}$ for figure 1 and a maximum of $294 \mathrm{~W}$ for figure 2. Result however showed a gradual decrease at the other hours, corresponding to the variation from noonday for the hours before noon. i.e. $11 \mathrm{am}=1 \mathrm{pm}$, $10 \mathrm{am}=2 \mathrm{pm}$ etc. at clear sky weather condition. Figure 3 , also replicated the same trend as the photovoltaic panel absorbed power according to the hourly radiation present but with a peak value of $135 \mathrm{~W}$.

Thus, photovoltaic panel output varies with the sun hours like solar radiation varies with the sun hours. The graph from a plot of $\mathrm{V}_{\text {ocv }}$ Versus hours is similar to graph from power $\mathrm{V}$ hours in [2] and also similar to figure 4 . Figure 4 represents a standard result got from standard models and it compares favorably with results obtained in this work.

\section{Conclusions}

The actual amount of solar radiation that is incident on photovoltaic panels as found from the work shows that extraterrestrial radiation value is greatly reduced as a result of weather and climatic conditions. It was however ascertained that:

a) The result obtained showed that photovoltaic output (instantaneous) in clear sky weather varies as solar output, with the time of the day.

b) For clear sky weather condition, solar radiation values are maximum at noonday ( the solar noon) and minimum values occurred during the dawn and night periods.

c) The power obtained from the table of voltages, generated from the power model, was used to estimate the amount of the hourly solar radiation that is present in Port Harcourt. 
d) Photovoltaic(PV)panel output can be used to estimate both the absorbed power by the PV and incident solar power, if the table of voltages for particular module is known.

\section{Acknowledgements}

My appreciation goes to Prof. F. J. K. Ideriah, Prof. B. T. Lebele-Alawa and Dr. B Nkoi.

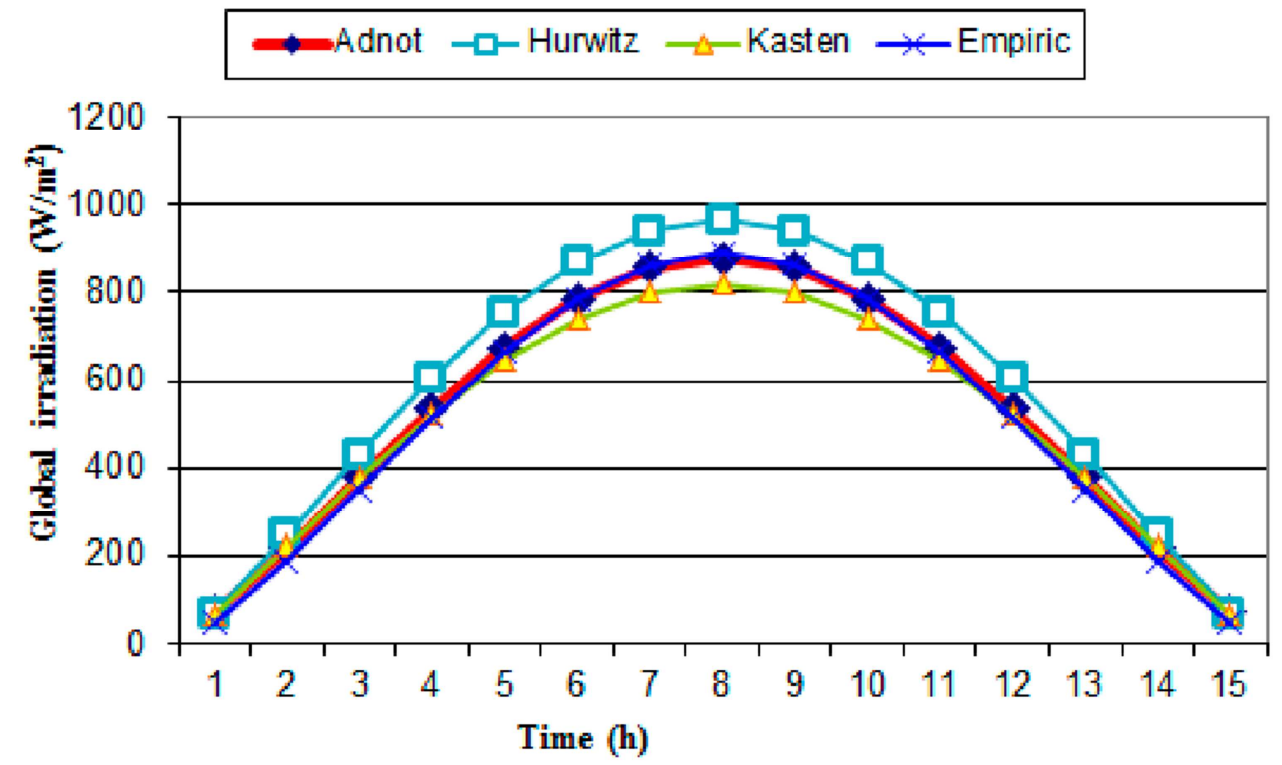

Figure 4. Hourly Variation of Solar Radiation [2].

\section{References}

[1] C. G. Popovici, S. V. Hudisteanu, T. D. Mateescu, \& N. C. Cheruchees, (2015). Efficiency improvement of photovoltaic panels by using air cooled heat. Sinks.

[2] I. L. Alboteanu, Bulucea, \& C. A., S. Degaralu, (2015). Estimating solar irradiation absorbed by Photovoltaic panels with low concentration located in Craiova, Romania. Sustainability 7 (2071-1050) 2644-2661 doi:10.3390/Su 7032644. www.mdi.com/journal/sustainability.

[3] D. O. Akpootu \& Y. A. Sanusi, (2015). A new temperature based model for estimating global solar radiation in Port Harcourt, south south Nigeria. IJES 4(1) 63-73 retrieved from www.thewes.com/papers/v4-1/version-1/kd411063073.pdf

[4] Z. Guo, (2017). Daily variation law of solar radiation flux density incident on the horizontal surface. Academy Science P. R. China. Journal of Earth Science and Climatic change, 8(4)12. DOI:10.4.72/2157-76.7, 10004.2.

[5] O. S. Ohunakin, M. S. Adaramola, O. M. Oyewola\& R. O. Fagbenle (2013). Correlations for Estimating Solar Radiation Using Sunshine Hours and Temperature Measurement in
Osogbo, Osun State, Nigeria. Front Energy,7(2), 214-222. DOI:10.1007/s11708-013-0241-2

[6] H. R. H. Liang, J. M. Zhang, J. A. Liu, Z. A. Sun, \& X. H. Cheng (2012). Estimation of Hourly Solar Radiation at the Surfaceunder Cloudless Conditions on the Tibetan Plateau Using a Simple Radiation Model. Adv. Atmos. Sciences,29(4), 675-689. DOI: $10.1007 / \mathrm{s} 00376-012-1157-1$

[7] S. S. Chandel \& R. K. Aggarwal (2011). Estimation of Hourly Solar Radiation on Horizontal and Inclined Surfaces in Western Hamalayas. Smart Grid and Renewable Energy Journal 2011 (2), 45-55. Doi:10.4236/sgre.2011.21006

[8] V. Ambas \& E. Baltas (2014) Spectral Analysis of Hourly Solar Radiation. Environmental processes, 1(3), 21-263. www.link.springer.com/article/10.1007/s40710-014-0023-9ss.

[9] R. K. C. Amadi, "The Regenerator as a Photovoltaic Recharger," unpublished.

[10] T. Khatib \& W. Elmenreich (2015). A Model of Hourly Solar Radiation Data Generation from Daily Solar Radiation Data Using a Generalized Regression Artificial Neural Network. International journal of photoenergy, 2015(4), 1-13 http://downloads.hindawi.com/journals/ijp/2015/968024.pd 